\title{
Detection of Myocardial Dysfunction using Global longitudinal strain with Speckle-Tracking Echocardiography in Patients with vs without Rheumatoid Arthritis: A Systematic Review and Meta- analysis
}

Vinay Kumar Thallapally ( $\nabla$ VinayKumarThallapally@creighton.edu )

Creighton University School of Medicine https://orcid.org/0000-0001-5916-6337

Raahat Bansal

Creighton University School of Medicine

Abhishek Thandra

Creighton University School of Medicine

Sonia Gupta

Creighton University School of Medicine

Sarah Aurit

Creighton University

Venkat S. Pajjuru

Creighton University School of Medicine

Dixitha Anugula

Creighton University School of Medicine

Aboeta Ahmed

Creighton University School of Medicine

Joseph Nahas

Creighton University School of Medicine

\section{Research Article}

Keywords: Rheumatoid Arthritis, Speckle tracking echocardiography, Global longitudinal strain, Subclinical cardiac dysfunction

Posted Date: February 7th, 2022

DOI: https://doi.org/10.21203/rs.3.rs-1282920/v1

License: () (1) This work is licensed under a Creative Commons Attribution 4.0 International License. Read Full License 


\section{Abstract}

Purpose Rheumatoid arthritis (RA) is a systemic autoimmune disorder primarily involving the peripheral joints. Systemic involvement can occur, including myocardial dysfunction. Speckle tracking echocardiography (STE) is a novel diagnostic study that is recently being used to detect subclinical cardiac dysfunction. Global longitudinal strain (GLS) by STE is more sensitive than standard echocardiographic parameters to detect occult cardiac dysfunction. Methods A systematic search of PUBMED, EMBASE, Cochrane, and Google Scholar databases was performed to identify studies comparing the STE parameters between RA and non-RA patients. Results Left ventricular (LV) GLS was significantly lower in patients with RA compared to non-RA patients with a standard mean difference (SMD) of -1.09 (-1.48 to $-0.70, \mathrm{P}<0.001)$. LV Global Circumferential Strain (GCS) was reported in five studies and it was found to be lower in RA patients with an SMD of -1.25 (-2.59 to $-0.10 ; P<0.0010)$. Meta-regression analysis studies failed to show any significant impact of disease duration, activity, age, sex, and BMI on LV GLS and RV GLS. Conclusions RA patients have lower LV GLS and LV GCS compared to controls suggesting impaired myocardial dysfunction. Further studies need to be done to delineate the importance of lower GLS in asymptomatic rheumatoid patients to guide disease management and risk factor modification in this selected population.

\section{Introduction}

Rheumatoid arthritis (RA) is a chronic systemic inflammatory autoimmune disease of unknown etiology that affects about 0.5 to $1 \%$ of the global adult population [1,2]. Previously, there has been established evidence of accelerated atherosclerotic coronary artery disease associated with chronic inflammation and resultant significant cardiovascular morbidity in RA [3]. However, recently research focus has shifted towards exploring the proposed mechanism of inflammation leading to congestive heart failure (CHF) in the RA patient cohorts [4,5]. The Incidence of CHF in RA was estimated at 21\%-34\% from the recent population-based cohort studies, and the disease activity in RA is strongly correlated with progression of CHF [6,7]. Given the early onset and accelerated risk of cardiovascular events in RA, early detection of subclinical cardiovascular disease including CHF is important to improve the overall prognosis.

Speckle tracking echocardiography (STE) is a novel diagnostic tool that can provide insight into the functionality of individual myocardial fiber layers and can be clinically utilized to assess subclinical and overt myocardial dysfunction. Specifically, Global longitudinal strain (GLS) by STE is more sensitive than left ventricular ejection fraction (LVEF) by conventional 2D echocardiogram to assess myocardial dysfunction [8]. Recent studies have supported the superior prognostic role of GLS for predicting major adverse cardiac events compared to LVEF $[9,10,11,12]$. Furthermore, a noninvasive imaging biomarker like GLS that assesses inflammatory myocardial dysfunction allows for personalized risk assessment in RA patients, helps maximize risk reduction strategies and will be an invaluable tool for research and clinical use. However, the role of GLS in identifying the early cardiovascular disease in RA patients is limited. Therefore, we performed a systematic review and meta-analysis of all published studies comparing myocardial function by GLS in RA versus non-RA patients.

\section{Materials And Methods}

An application was initially submitted to Creighton University biomedical IRB and received an exempt status.

This systematic review and meta-analysis were conducted in accordance with Cochrane collaboration guidelines and reported according to the Preferred Reporting Items for Systematic Review and Meta-Analysis Protocols (PRISMA) [13,14].

A comprehensive search of major electronic databases including PubMed, EMBASE, Cochrane reviews, and Scopus was conducted from inception through September 2020, by two independent reviewers (VT and RB). The following keywords were used: "speckle tracking echocardiography", "Rheumatoid arthritis", "global longitudinal strain", and "circumferential strain". The search strategy was not limited by language and publication year.

The reference lists of selected articles were manually reviewed. We did not attempt to contact the authors of the articles for retrieving additional information or clarifications. Inclusion criteria: 1) Studies including 2 groups with and without RA and reported their data as mean with standard deviations. 2) Studies reported outcomes of left ventricular (LV) global longitudinal strain (GLS) and/or Global circumferential strain (GCS), and/or right ventricular (RV) strain in both groups. 3) Patients with underlying ischemic 
heart disease and heart failure were excluded in the selected studies. Case reports, case series without a control group, reviews, and animal studies were excluded.

\section{Data extraction:}

The data extraction was performed using a pre-specified data collection form. The collected data included baseline characteristics of the included studies and participants, sample sizes, and outcomes values. The primary outcome of interest was left ventricular global longitudinal strain, and the secondary outcomes were LV circumferential strain and right ventricular GLS.

\section{Statistical analysis:}

For each study, all outcome data were abstracted as reported or figure-calculated means and standard deviations, which were utilized to conduct a random-effects meta-analysis. The standard deviations from both the RA and non-RA patient groups were pooled in order to calculate standardized mean differences (SMDs). We examined heterogeneity between studies with the $\mathrm{I}^{2}$ statistic based on Cochran's Q ( $0 \%$ to $100 \%)$. Heterogeneity was defined as low ( $25 \%$ to $50 \%)$, moderate (50\% to $75 \%)$, or high (>75\%).

Regarding meta-regression, we evaluated heterogeneity across studies with a likelihood ratio test (LRT) for each outcome, which was estimated as the difference of -2 REML log-likelihoods generated from models with and without a random effect of study for each outcome. The resulting difference (LR) was assumed to follow a chi-square distribution with one degree of freedom. We added the study-specific factor of the mean duration of disease and DAS28 separately if there were at least three studies with available information. We examined age, BMI, gender, ESR, and CRP in a similar manner. For each predictor, we calculated the Pearson correlation coefficient and presented it as $\mathrm{R}^{2}$ to examine the relationship with the predicted outcome. SAS v. 9.4 (SAS Institute, Inc, Cary, NC) and Stata 15.1 were used for all analyses; $P<0.05$ indicates statistical significance.

\section{Results}

Overall, a total of 13 studies with 1516 patients were included in the meta-analysis that met predefined inclusion and exclusion criteria (Figure 1) [15-27]. The major characteristics of all the included studies and baseline characteristics are outlined in Table 1 and Table 2. The mean age was 52.7 years and about $68 \%$ were females.

\section{GLS and GCS:}

All the 13 studies reported data on LV GLS, and the pooled analysis showed LV GLS was significantly lower in patients with RA compared to non-RA patients with a SMD of -1.09 (95\% Cl: -1.48 to $-0.70, P<0.001)$ with a high heterogeneity of $\mathrm{I}^{2}=91.2 \%$ (Figure 2).

The LV GCS was reported in five studies, and it was found to be lower in RA patients with an SMD of -1.25 (95\% Cl: -2.59 to -0.10 ; $P<$ $0.001 ; I^{2}=96.7 \%$ ) (Figure 3 ).

Meta-regression model of the studies on LV GLS did not show any impact of disease duration (effect size change for every additional year of disease duration: $0.09,95 \% \mathrm{Cl}$ : -0.02 to $0.20, P=0.088$ ) or DAS28 (effect size change for every additional unit of DAS28: $-0.14,95 \% \mathrm{Cl}:-0.80$ to $0.51, P=0.623$ ) (Table 3). Disease duration and DAS28 explained $28.9 \%$ and $3.6 \%$ of the total variability, respectively. Similarly, no effect was found for age, BMI, gender, ESR and CRP. 
Four studies reported RV GLS and there was no statistical evidence of a difference between RA and non-RA patients with an SMD of -0.54 (95\% Cl: -1.47 to $0.39 ; P=0.254) ; I^{2}=94.0 \%$ (Figure 4$)$.

There was no statistical evidence of a change in effect size upon examination of disease duration (effect size change for every additional year of disease duration: $0.89,95 \% \mathrm{Cl}$ : -2.09 to $3.87, P=0.164$ ), which explained $93.4 \%$ of the total variability (Table 4 ). There was no relationship between age, gender, and CRP to RVGLS.

\section{Discussion}

In our meta-analysis, we investigated the STE parameters including LV GLS, LV GCS, and RV GLS among patients with and without RA. The major findings were: 1) The RA patients had reduced LV GLS and GCS when compared to non-RA patients. 2) There is no statistically significant difference in RV GLS between RA patients and non-RA patients. 3) The disease duration, disease activity (DAS28), age, sex, ESR, and CRP levels did not have an impact on the overall LV and RV GLS.

\section{Pathophysiology of LV dysfunction in RA:}

Various pathophysiological mechanisms have been studied for a better understanding of HF in patients with chronic inflammation. It is proposed that cardiac myocytes react to chronic inflammation by producing cytokines and cell adhesion molecules, which increases the recruitment of leukocytes within the cardiac cell and reduces the myocardial contractility [28]. In addition, according to Lim et al, chronic inflammation leads to microvascular and endothelial dysfunction which causes myocardial remodeling and fibrosis, leading to LV dysfunction [29]. Similar evidence was demonstrated using evaluation with Cardiac magnetic resonance (CMR) which offers reliable information regarding myocardial inflammation and fibrosis. CMR findings on T2- weighted imaging and late gadolinium enhancement suggestive of inflammation and fibrosis respectively, were significantly associated with higher NT-proBNP among RA patients. This suggests that alterations in myocardial structure precede clinical HF [30].

\section{Speckle-tracking Echocardiography:}

The LV myocardium has a spiral architecture with myocardial fibers in two orientations, longitudinal in the endocardial region and epicardial region, and circumferential in the mid-wall. This contributes to longitudinal, circumferential, and radial strain during LV contraction. In addition, the helical orientation of the myocardial fibers results in LV torsional strain from a twisting motion. Assessment of LV function using ejection fraction (EF) alone has intrinsic limitations of inter and intraobserver variability [31]. Speckle-tracking is a sophisticated semi-automated method to evaluate the complicated myocardial mechanics and LV strain [32]. It addresses the limitations of EF and is currently considered the most accurate and sensitive parameter for the assessment of early left ventricular dysfunction. GLS was noted to be more reproducible and clinically useful compared to circumferential and radial strains [33,34].

\section{Significance of Measuring Strain using STE in RA:}

In 2009, Ikonomidis et al first studied association of RA with reduced LV GLS in a small cohort of 46 patients and later several investigators reported similar results. The findings of our meta-analysis are consistent with prior reports and by including about 1516 patients ( 861 with RA and 665 without RA) we increased the power to estimate the association between RA and early myocardial dysfunction. Recently, a large cohort study by Mantel et al including about 12,943 newly diagnosed and 45k established RA patients showed the increased risk of nonischemic cardiomyopathy in RA patients with Hazard's ration of 2.06 (95\% Cl: 1.37 to $3.20)$ and 1.71 (95\% Cl: 1.57 to 1.87$)$ respectively [35].

In our cohort, the prevalence of traditional risk factors for cardiovascular disease including hypertension (21.3\%), diabetes (5.5\%), obesity and cigarette smoking was low when compared to the population within this age group (In age group 40-59 yrs, prevalence of hypertension and diabetes was $33 \&$ and $10 \%$ respectively). Even with this low burden of comorbidities, RA patients had lower LV 
GLS, suggesting this finding may be used as a better risk predictor for cardiovascular disease compared to the traditional risk factors.

Naseem et al in 2018 established that there is a positive correlation between disease activity (DAS28 score) and reduction in RV and LV GLS [25]. A significant improvement in GLS with better disease control while undergoing treatment with TNF and Interleukin inhibitors has also been shown [15-18, 36]. In contradiction, the meta-regression model of our analysis did not find any association between GLS and disease duration or activity or inflammatory markers. This can possibly be explained by the loss of individual patient characteristics in the pooled analysis.

Right ventricular GLS by STE is a better indicator of RV function when compared to conventional echocardiographic parameters like RV fractional area change (FAC) and tricuspid annular plane systolic excursion (TAPSE) [37-39]. This can be used as a prognostic tool in assessing the mortality risk among patients with heart failure [40,41]. However, the clinical relevance of detecting RV dysfunction in patients without any cardiovascular disease is not well established.

\section{Limitations:}

Potential limitations for our study include differences in inclusion and exclusion criteria of the studies included and the differences in the patient characteristics in terms of cardiovascular risk factors and comorbidities. Meta regression analysis done failed to reveal any correlation to age, sex, BMI and disease activity. This was surprising as we suspected patients with more severe RA, characterized by high disease activity or inflammatory markers would have worsened cardiac dysfunction in our pooled analysis. Loss of individual patient characteristics in the pooled analysis might possibly be responsible for this.

There is significant heterogeneity documented among studies on LVGLS, LV GCS and RV GLS. Although GLS is more reproducible and reliable compared to other strain parameters, there is a concern for heterogeneity among comparison of data extracted by different echocardiography machines and different software used. We accounted for the heterogeneity among the studies by using a random effects approach in the meta-analysis.

\section{Future Directions:}

Overall, there is an increased incidence of HF in RA patients, and with STE we can detect early cardiac dysfunction. Among patients undergoing anthracycline-based chemotherapy, LV surveillance using GLS had increased the use of cardioprotective therapy (beta-blocker or Angiotensin converting enzyme inhibitor/Angiotensin receptor blocker) thereby reducing the incidence of cardiac dysfunction [42]. While there is no supportive evidence of starting cardioprotective medications in RA patients with low GLS at this time, we believe there is a necessity for further research in this area.

\section{Conclusion}

STE can detect and measure subclinical myocardial dysfunction in rheumatoid arthritis patients facilitating better risk prediction for cardiovascular disease and personalized treatment in this high-risk group. Further studies are necessary to establish the role of early screening for myocardial dysfunction and starting cardioprotective therapy among this patient population.

\section{References}

1. Myasoedova E, Crowson CS, Kremers HM, Therneau TM, Gabriel SE. Is the incidence of rheumatoid arthritis rising?: Results from olmsted county, minnesota, 1955-2007. Arthritis Rheum. 2010; 62: 1576-82.

2. Hunter TM, Boytsov NN, Zhang X, Schroeder K, Michaud K, Araujo AB. Prevalence of rheumatoid arthritis in the united states adult population in healthcare claims databases, 2004-2014. Rheumatol Int. 2017; 37: 1551-7. 
3. Van Doornum S, McColl G, Wicks IP. Accelerated atherosclerosis: An extraarticular feature of rheumatoid arthritis?. Arthritis \& Rheumatism: Official Journal of the American College of Rheumatology. 2002; 46: 862-73.

4. Maradit-Kremers H, Crowson CS, Nicola PJ, Ballman KV, Roger VL, Jacobsen SJ, et al. Increased unrecognized coronary heart disease and sudden deaths in rheumatoid arthritis: A population-based cohort study. Arthritis \& Rheumatism: Official Journal of the American College of Rheumatology. 2005; 52: 402-11.

5. Crowson CS, Nicola PJ, Kremers HM, O'Fallon WM, Therneau TM, Jacobsen SJ, et al. How much of the increased incidence of heart failure in rheumatoid arthritis is attributable to traditional cardiovascular risk factors and ischemic heart disease?. Arthritis \& Rheumatism: Official Journal of the American College of Rheumatology. 2005; 52: 3039-44.

6. Nicola PJ, Maradit-Kremers H, Roger VL, Jacobsen SJ, Crowson CS, Ballman KV, et al. The risk of congestive heart failure in rheumatoid arthritis: A population-based study over 46 years. Arthritis \& Rheumatism: Official Journal of the American College of Rheumatology. 2005; 52: 412-20.

7. Solomon DH, Reed GW, Kremer JM, Curtis JR, Farkouh ME, Harrold LR, et al. Disease activity in rheumatoid arthritis and the risk of cardiovascular events. Arthritis \& rheumatology. 2015; 67: 1449-55.

8. Imbalzano E, Zito C, Carerj S, Oreto G, Mandraffino G, Cusmà-Piccione M, et al. Left ventricular function in hypertension: New insight by speckle tracking echocardiography. Echocardiography. 2011; 28: 649-57.

9. Freed BH, Daruwalla V, Cheng JY, Aguilar FG, Beussink L, Choi A, et al. Prognostic utility and clinical significance of cardiac mechanics in heart failure with preserved ejection fraction: Importance of left atrial strain. Circulation: Cardiovascular Imaging. 2016; 9: e003754.

10. Donal E, Lund LH, Oger E, Hage C, Persson H, Reynaud A, et al. New echocardiographic predictors of clinical outcome in patients presenting with heart failure and a preserved left ventricular ejection fraction: A subanalysis of the ka (karolinska) ren (rennes) study. European journal of heart failure. 2015; 17: 680-8.

11. Shah AM, Claggett B, Sweitzer NK, Shah SJ, Anand IS, Liu L, et al. Prognostic importance of impaired systolic function in heart failure with preserved ejection fraction and the impact of spironolactone. Circulation. 2015; 132: 402-14.

12. Park JJ, Park J, Park J, Cho G. Global longitudinal strain to predict mortality in patients with acute heart failure. J Am Coll Cardiol. 2018; 71: 1947-57.

13. Higgins JP, Altman DG, Gøtzsche PC, Jüni P, Moher D, Oxman AD, et al. The cochrane collaboration's tool for assessing risk of bias in randomised trials. BMJ. 2011; 343.

14. Shamseer L, Moher D, Clarke M, Ghersi D, Liberati A, Petticrew M, et al. Preferred reporting items for systematic review and metaanalysis protocols (PRISMA-P) 2015: Elaboration and explanation. BMJ. 2015; 349.

15. Ikonomidis I, Tzortzis S, Lekakis J, Paraskevaidis I, Andreadou I, Nikolaou M, et al. Lowering interleukin-1 activity with anakinra improves myocardial deformation in rheumatoid arthritis. Heart. 2009; 95: 1502-7.

16. Fine NM, Crowson CS, Lin G, Oh JK, Villarraga HR, Gabriel SE. Evaluation of myocardial function in patients with rheumatoid arthritis using strain imaging by speckle-tracking echocardiography. Ann Rheum Dis. 2014; 73: 1833-9.

17. Ikonomidis I, Tzortzis S, Andreadou I, Paraskevaidis I, Katseli C, Katsimbri P, et al. Increased benefit of interleukin-1 inhibition on vascular function, myocardial deformation, and twisting in patients with coronary artery disease and coexisting rheumatoid arthritis. Circulation: Cardiovascular Imaging. 2014; 7: 619-28.

18. Ayyildiz YO, Vural MG, Efe TH, Ertem AG, Koseoglu C, Ayturk M, et al. Effect of long-term TNF-a inhibition with infliximab on left ventricular torsion in patients with rheumatoid arthritis. Hellenic J Cardiol. 2015; 56: 406-13. 
19. Magda SL, Mincu RI, Florescu M, Ciobanu AO, Udrea GF, Cinteza M, et al. The assessment of subclinical cardiovascular dysfunction in treated rheumatoid arthritis. Maedica. 2016;11: 267.

20. Midtb $\varnothing$ H, Semb AG, Matre K, Kvien TK, Gerdts E. Disease activity is associated with reduced left ventricular systolic myocardial function in patients with rheumatoid arthritis. Ann Rheum Dis. 2017; 76: 371-6.

21. Mohamed LA, Maghraby HM, Saleh AM. Early detection of left ventricular systolic dysfunction in asymptomatic patients with rheumatoid arthritis using global longitudinal strain assessment.

22. Tarek El-Zawawy H, Helal A, Zaki T, Galal H, Mohamed Allam M, Hussein Elzawawy T, et al. CardioAlex 2017 conference proceedings abstracts. European Heart Journal Supplements. 2017; 19: G1-8.

23. Cioffi G, Ognibeni F, Dalbeni A, Giollo A, Orsolini G, Gatti D, et al. High prevalence of occult heart disease in normotensive patients with rheumatoid arthritis. Clin Cardiol. 2018; 41: 736-43.

24. Gullo AL, Rodríguez-Carrio J, Aragona CO, Dattilo G, Zito C, Suárez A, et al. Subclinical impairment of myocardial and endothelial functionality in very early psoriatic and rheumatoid arthritis patients: Association with vitamin $D$ and inflammation. Atherosclerosis. 2018; 271: 214-22.

25. Naseem M, Samir S, Ibrahim IK, Khedr L, Shahba AAE. 2-D speckle-tracking assessment of left and right ventricular function in rheumatoid arthritis patients with and without disease activity. Journal of the Saudi Heart Association. 2019; 31: 41-9.

26. Hanvivadhanakul P, Buakhamsri A. Disease activity is associated with LV dysfunction in rheumatoid arthritis patients without clinical cardiovascular disease. Advances in Rheumatology. 2019; 59.

27. Nikdoust F, Safiarian S, Mostafavi A, Gharibdoust F, Tabatabaei SAH. Assessment of global longitudinal strain via speckletracking echocardiography in patients with rheumatoid arthritis. Iranian Heart Journal. 2020; 21: 103-9.

28. Marchant DJ, Boyd JH, Lin DC, Granville DJ, Garmaroudi FS, McManus BM. Inflammation in myocardial diseases. Circ Res. 2012; 110: 126-44.

29. Lim SL, Lam CS, Segers VF, Brutsaert DL, De Keulenaer GW. Cardiac endothelium-myocyte interaction: Clinical opportunities for new heart failure therapies regardless of ejection fraction. Eur Heart J. 2015; 36: 2050-60.

30. Holmström M, Koivuniemi R, Korpi K, Kaasalainen T, Laine M, Kuuliala A, et al. Cardiac magnetic resonance imaging reveals frequent myocardial involvement and dysfunction in active rheumatoid arthritis. Clin Exp Rheumatol. 2016; 34: 416-23.

31. Benameur N, Arous Y, Ben Abdallah N, Kraiem T. Comparison between 3D echocardiography and cardiac magnetic resonance imaging (CMRI) in the measurement of left ventricular volumes and ejection fraction. Current Medical Imaging. 2019; 15: 654-60.

32. Neisius U, Myerson L, Fahmy AS, Nakamori S, El-Rewaidy H, Joshi G, et al. Cardiovascular magnetic resonance feature tracking strain analysis for discrimination between hypertensive heart disease and hypertrophic cardiomyopathy. PloS one. 2019; 14 : e0221061.

33. Morbach C, Walter BN, Breunig M, Liu D, Tiffe T, Wagner M, et al. Speckle tracking derived reference values of myocardial deformation and impact of cardiovascular risk factors-Results from the population-based STAAB cohort study. PloS one. 2019; 14: e0221888.

34. Mantel $\ddot{A}$, Holmqvist M, Andersson DC, Lund LH, Askling J. Association between rheumatoid arthritis and risk of ischemic and nonischemic heart failure. J Am Coll Cardiol. 2017; 69: 1275-85.

35. Atzeni F, Gianturco L, Boccassini L, Sarzi-Puttini P, Bonitta G, Turiel M. Noninvasive imaging methods for evaluating cardiovascular involvement in patients with rheumatoid arthritis before and after anti-TNF drug treatment. Future science OA. 2019; 5: FSO396. 
36. Park SJ, Park J, Lee HS, Kim MS, Park YK, Park Y, et al. Impaired RV global longitudinal strain is associated with poor long-term clinical outcomes in patients with acute inferior STEMI. JACC: Cardiovascular imaging. 2015; 8: 161-9.

37. Zornoff LA, Skali H, Pfeffer MA, St. John Sutton M, Rouleau JL, Lamas GA, et al. Right ventricular dysfunction and risk of heart failure and mortality after myocardial infarction. J Am Coll Cardiol. 2002; 39: 1450-5.

38. Holman WL, Kormos RL, Naftel DC, Miller MA, Pagani FD, Blume E, et al. Predictors of death and transplant in patients with a mechanical circulatory support device: A multi-institutional study. The Journal of Heart and Lung Transplantation. 2009; 28 : 44-50.

39. Hinojar Baydes R, De Angelis V, Garcia-Martin A, Gonzalez-Gomez A, Sanroman M, Pascual M, et al. Prognostic value of right ventricular systolic function by speckle tracking echocardiography beyond conventional echocardiography in significant tricuspid regurgitation. Eur Heart J. 2020; 41: ehaa946. 1912.

40. Morris DA, Krisper M, Nakatani S, Köhncke C, Otsuji Y, Belyavskiy E, et al. Normal range and usefulness of right ventricular systolic strain to detect subtle right ventricular systolic abnormalities in patients with heart failure: A multicentre study. European Heart Journal-Cardiovascular Imaging. 2017; 18: 212-23.

41. Thavendiranathan P, Negishi T, Somerset E, Negishi K, Penicka M, Lemieux J, et al. Strain-guided management of potentially cardiotoxic cancer therapy. J Am Coll Cardiol. 2021; 77: 392-401.

\section{Declarations}

Funding:

The authors declare that no funds, grants, or other support were received during the preparation of this manuscript.

Competing interest:

The authors have no relevant financial or non-financial interests to disclose.

Authors contribution:

All authors contributed to the study conception and design. Material preparation, data collection and analysis were performed by [Raahat Bansal] [Sonia Gupta] [Venkat s. Pajjuru] [Dixitha Anugula] and [sarah Aurit]. The first draft of the manuscript was written by [Vinay K. Thallapally] [Abhishek Thandra] [Ahmed Aboeata] [Joseph Nahas] and all authors commented on previous versions of the manuscript. All authors read and approved the final manuscript.

Ethics:

This is a meta-analysis, and no ethical approval is required.

\section{Abbreviations}

LVEF: Left ventricular Ejection Fraction

STE: Speckle Tracking Echocardiography

GLS: Global Longitudinal Strain

GCS: Global Circumferential strain

SMD: Standard mean difference

\section{Tables}

Table 1. Studies included in the meta-analysis and individual characteristics. 
Page $9 / 15$ 


\begin{tabular}{|c|c|c|c|c|}
\hline Study & Type of study & Countries & Strain software & Comments \\
\hline $\begin{array}{c}\text { Ikonomidis et al, } \\
2009 \\
\mathrm{n}=69 \\
\mathrm{RA}=46 \\
\text { Non-RA }=23\end{array}$ & $\begin{array}{l}\text { Observational } \\
\text { study }\end{array}$ & Greece & $\begin{array}{l}\text { Echopac } \\
\text { (GE Medical systems, Horten, } \\
\text { Norway) }\end{array}$ & $\begin{array}{c}\text { The LV GLS strain was lower in RA patients }(-18.5 \% \text { vs } \\
-22.5 \%, \mathrm{P}=0.002) \text {. } \\
\text { LV dysfunction improved in patients after treatment } \\
\text { with IL- } 1 \text { inhibitors. }\end{array}$ \\
\hline $\begin{array}{l}\text { Fine et al, } 2014 \\
n=118 \\
\text { RA=59 } \\
\text { Non-RA }=59 \\
\text { hales }=90\end{array}$ & $\begin{array}{l}\text { Observational } \\
\text { study, } \\
\text { retrospective }\end{array}$ & $\begin{array}{l}\text { Minnesota, } \\
\text { USA }\end{array}$ & $\begin{array}{l}\text { Syngo Velocity Vector Imaging } \\
\text { (VVI) software (version 3.5) } \\
\text { (Siemens Medical Solutions, } \\
\text { Malvern, Pennsylvania) }\end{array}$ & $\begin{array}{c}\text { Global LV strain reduced in RA patients compared to } \\
\text { control group }(-15.7 \pm 3.2 \% \text { vs }-18.1 \pm 2.4 \%, \mathrm{P}<0.001) \text {. } \\
\text { RA patients had reduced RV GLS. } \\
\text { The reduced strain values are associated with RA } \\
\text { disease severity and treatment. }\end{array}$ \\
\hline $\begin{array}{c}\text { Ikonomidis et al, } \\
2014 \\
\mathrm{n}=50 \\
\mathrm{RA}=20 \\
\text { Non-RA }=30\end{array}$ & $\begin{array}{l}\text { Double blind } \\
\text { randomized } \\
\text { control trial }\end{array}$ & Greece & $\begin{array}{l}\text { Echopac } \\
\text { (GE Medical systems, Horten, } \\
\text { Norway) }\end{array}$ & $\begin{array}{l}\text { After anakinra, there was a greater improvement in } \\
\text { longitudinal strain values ( } 33 \pm 5 \% \text { vs } 18 \pm 2 \%) \text {. }\end{array}$ \\
\hline $\begin{array}{l}\text { Ayylidiz et al, } \\
2015 \\
\text { n=68 } \\
\text { RA }= \\
\text { Non-RA }=\end{array}$ & $\begin{array}{l}\text { Observational } \\
\text { study, } \\
\text { Prospective }\end{array}$ & Turkey & $\begin{array}{l}\text { QLAB } 6.0 \\
\text { (Philips Medical Systems, } \\
\text { Bothell, Washington, USA) }\end{array}$ & $\begin{array}{c}\text { The LV GLS was lower in RA patients (16.5\% vs } 20 \% \text {, P } \\
<0.01) \text {. } \\
\text { Patients treated with infliximab experienced a } \\
\text { significant increase in GLS. No significant changes } \\
\text { were observed among patients treated with } \\
\text { prednisolone. }\end{array}$ \\
\hline $\begin{array}{l}\text { Magda et al, } \\
2016 \\
n=46 \\
\text { RA }=29 \\
\text { Non-RA }=17\end{array}$ & $\begin{array}{l}\text { Cross } \\
\text { sectional } \\
\text { study }\end{array}$ & Romania & Not reported & $\begin{array}{c}\text { Correctly treated RA with normal inflammatory } \\
\text { markers have reduced RV GLS suggesting subclinical } \\
\text { RV dysfunction. }\end{array}$ \\
\hline $\begin{array}{l}\text { Midtbo et al, } \\
2016 \\
\mathrm{n}=124 \text { (active } \\
\text { RA vs control) } \\
\text { RA }=78 \\
\text { Non-RA }=46\end{array}$ & $\begin{array}{l}\text { Observational } \\
\text { study, } \\
\text { retrospective }\end{array}$ & Norway & $\begin{array}{l}\text { EchoPAC BT12 software (GE } \\
\text { Vingmed Ultrasound) }\end{array}$ & $\begin{array}{c}\text { Active RA patients had lower LV GLS compared to RA } \\
\text { patients in remission and control group. } \\
\text { No significant difference in GLS among RA patients in } \\
\text { remission vs controls. }\end{array}$ \\
\hline $\begin{array}{l}\text { Mohammed et } \\
\text { al, } 2016 \\
n=83 \\
\text { RA=50 } \\
\text { Non-RA }=33\end{array}$ & $\begin{array}{l}\text { Observational } \\
\text { study, single } \\
\text { center }\end{array}$ & Egypt & EchoPAC version 110.1.2 & $\begin{array}{l}\text { LV GLS is reduced in RA compared to controls }(-17.2 \% \\
\text { vs }-21.9 \%, P<0.05)\end{array}$ \\
\hline $\begin{array}{l}\text { Hamdy et al, } \\
2017 \\
n=90 \\
\text { RA }=50 \\
\text { Non- } R A=40\end{array}$ & $\begin{array}{l}\text { Cross } \\
\text { sectional } \\
\text { study }\end{array}$ & Egypt & EchoPAC version 110.1.2 & $\begin{array}{l}\text { LV GLS is low in RA patients }(-17.7 \% \text { vs } 20 \% \text {, } \\
\text { P=0.0001). } \\
\text { LV GLS significant negative correlation with disease } \\
\text { activity (DAS } 28 \text { score) and inflammatory markers } \\
\text { (ESR and CRP). }\end{array}$ \\
\hline $\begin{array}{l}\text { Cioffi et al, } 2018 \\
\mathrm{n}=388 \\
\text { RA= } \\
\text { Non-RA }=\end{array}$ & $\begin{array}{l}\text { Observational } \\
\text { study, } \\
\text { prospective }\end{array}$ & Italy & $\begin{array}{l}\text { XStrain 2D speckle-tracking } \\
\text { technology software (Esaote } \\
\text { Biomedica) }\end{array}$ & $\begin{array}{l}\text { In normotensive cohort, RA patients had lower GLS } \\
\text { compared to controls ( }-18.6 \% \text { vs } 20 \%, \mathrm{P}=0.02) \\
\text { LV GLS is an independent predictor of all-cause and } \\
\text { cardiovascular hospitalizations among normotensive } \\
\text { RA patients. }\end{array}$ \\
\hline $\begin{array}{l}\text { Gullo et al, } 2018 \\
\mathrm{n}=99 \\
\mathrm{RA}=41 \\
\text { Non-RA }=48\end{array}$ & $\begin{array}{l}\text { Observational } \\
\text { study, } \\
\text { prospective }\end{array}$ & Italy & EchoPAC, version 8.0.0 & $\begin{array}{c}\text { RA patients exhibited impaired GLS }(-18 \% \text { vs }-23 \% \text {, } \\
\mathrm{P}<0.001 \%) \text { and GCS }(-20 \% \text { vs }-24.5 \%, \mathrm{P}<0.001) \\
\text { compared to healthy controls with negative correlation } \\
\text { to disease activity (DAS } 28 \text { score) }\end{array}$ \\
\hline $\begin{array}{l}\text { Naseem et al, } \\
2018 \\
\mathrm{n}=121 \\
\mathrm{RA}=81 \\
\text { Non-RA=40 } \\
\text { Remission }=39\end{array}$ & $\begin{array}{l}\text { Observational } \\
\text { study, } \\
\text { prospective }\end{array}$ & Egypt & $\begin{array}{l}\text { Echo Pac, GE Vivid E9 } \\
\text { echocardiography system } \\
\text { version } 113\end{array}$ & $\begin{array}{c}\text { RA patients had reduced LV GLS and RV GLS with } \\
\text { negative correlation with RA disease activity (DAS28 } \\
\text { and SDAI score). }\end{array}$ \\
\hline $\begin{array}{c}\text { Hanvivadhanakul } \\
\text { et al, } 2019 \\
n=120\end{array}$ & $\begin{array}{l}\text { Cross } \\
\text { sectional } \\
\text { study }\end{array}$ & Thailand & $\begin{array}{c}\text { Excelera workstation (QLAB11, } \\
\text { Philips) }\end{array}$ & $\begin{array}{l}\text { LV GLS significantly lower in RA patient's vs controls } \\
\qquad(-17.6 \% \text { vs } 20.4 \%, P=0.03)\end{array}$ \\
\hline
\end{tabular}




\begin{tabular}{|c|c|c|c|c|}
$\begin{array}{c}\text { RA=60 } \\
\text { Non-RA=60 }\end{array}$ & & & $\begin{array}{c}\text { Multivariate regression analysis demonstrated } \\
\text { significant correlations between subclinical LV } \\
\text { dysfunction with disease duration and activity. }\end{array}$ \\
\hline $\begin{array}{c}\text { Nikdoust et al, } \\
2020 \\
\mathrm{n}=70 \\
\text { RA=35 } \\
\text { Non-RA=35 }\end{array}$ & $\begin{array}{c}\text { Observational } \\
\text { study, } \\
\text { retrospective }\end{array}$ & Iran & Not reported & $\begin{array}{c}\text { LV and RV GLS was significantly reduced in RA patient } \\
\text { compared to healthy subjects (-19.5\% vs -20.4\% and } \\
-18.7 \% \text { vs }-21.7 \%) .\end{array}$ \\
\hline
\end{tabular}

RA=Rheumatoid arthritis; GLS=Global Longitudinal strain; GCS=Global circumferential strain; LV=Left ventricle; RV=Right ventricle

Table 2. Demographic and clinical data of subjects enrolled in included studies

\begin{tabular}{|c|c|c|c|c|c|c|c|c|c|}
\hline study & $\begin{array}{c}\text { RA* }^{*} \\
\text { patients } \\
(\mathrm{n})\end{array}$ & $\begin{array}{l}\text { Non-RA } \\
\text { controls } \\
\text { (n) }\end{array}$ & $\begin{array}{c}\text { Age } \\
\text { (years) }\end{array}$ & Females(n) & $\underset{(\mathrm{kg} / \mathrm{m} 2)}{\mathrm{BMI}}$ & $\begin{array}{c}\text { Hypertension } \\
(\%)\end{array}$ & $\underset{(\%)}{\text { Smokers }}$ & $\underset{(\%)}{\text { Hyperlipidemia }}$ & $\begin{array}{c}\text { Diabetes } \\
(\%)\end{array}$ \\
\hline ikonomidis et al & 46 & 23 & 56 & 31 & 28.6 & 20 & 13 & 13 & 9 \\
\hline Fine et al & 59 & 59 & 55.7 & 45 & 29.1 & 50 & 26 & 42 & 8 \\
\hline Ikonomidis et al & 20 & 30 & 58 & 14 & 29.3 & 9 & 8 & $\mathrm{~N} / \mathrm{A}$ & $\mathrm{N} / \mathrm{A}$ \\
\hline Ayyildiz et al & 38 & 30 & 52.1 & 38 & 30.5 & 10 & 5 & 2 & 8 \\
\hline Magda et al & 29 & 17 & 55.5 & 28 & 27 & 16 & 0 & 13 & 1 \\
\hline Midtbø et al & $\begin{array}{l}78 \\
41\end{array}$ & 46 & $\begin{array}{l}60.7 \\
62.1\end{array}$ & $\begin{array}{l}60 \\
31\end{array}$ & $\begin{array}{l}25.5 \\
25.6\end{array}$ & 0 & $\begin{array}{c}19 \\
6\end{array}$ & 0 & 0 \\
\hline Mohamed & 50 & 33 & 45.8 & 44 & $\mathrm{~N} / \mathrm{A}$ & 0 & $\mathrm{~N} / \mathrm{A}$ & $\mathrm{N} / \mathrm{A}$ & $\mathrm{N} / \mathrm{A}$ \\
\hline Hamdy et al & 50 & 40 & 35.4 & 46 & N/A & $\mathrm{N} / \mathrm{A}$ & $\mathrm{N} / \mathrm{A}$ & N/A & N/A \\
\hline Cioffi et al & 194 & 194 & 54 & 63 & 24.4 & 0 & 40 & 52 & 3 \\
\hline Gullo et al & 41 & 58 & 46.5 & 32 & 25.15 & 0 & 0 & 0 & 0 \\
\hline Naseem et al & 120 & 40 & $\begin{array}{l}54.52 \\
55.08\end{array}$ & $\begin{array}{l}55 \\
27\end{array}$ & $\mathrm{~N} / \mathrm{A}$ & 0 & $\begin{array}{c}12 \\
7\end{array}$ & N/A & 0 \\
\hline $\begin{array}{l}\text { Hanvivadhanakul } \\
\text { et al }\end{array}$ & 60 & 60 & 50 & 55 & 22 & 0 & 3 & 17 & 0 \\
\hline Nikdoust et al & 35 & 35 & 43.33 & & $\mathrm{~N} / \mathrm{A}$ & $\mathrm{N} / \mathrm{A}$ & $\mathrm{N} / \mathrm{A}$ & $\mathrm{N} / \mathrm{A}$ & $\mathrm{N} / \mathrm{A}$ \\
\hline
\end{tabular}

$* \mathrm{RA}=$ Rheumatoid arthritis

Table 3: Meta-regression analysis - Impact of various variables on change in effect size of Left Ventricular Global Longitudinal strain in Rheumatoid Arthritis.

\begin{tabular}{|l|c|c|c|}
\hline & Estimate $(95 \% \mathrm{CI})$ & $P$ & $R^{2}$ \\
\hline Disease Duration (per additional year) & $0.09(-0.02$ to 0.20$)$ & 0.088 & 0.289 \\
\hline DAS28 (per 1 unit increase) & $-0.14(-0.80$ to 0.51$)$ & 0.623 & 0.036 \\
\hline Age (per additional year) & $0.03(-0.05$ to 0.10$)$ & 0.411 & 0.062 \\
\hline BMI (per $1 \mathrm{~kg} / \mathrm{m}^{2}$ increase) & $-0.01(-0.30$ to 0.28$)$ & 0.932 & 0.001 \\
\hline Gender (per $1 \%$ increase) & $-0.01(-0.04$ to 0.03$)$ & 0.791 & 0.007 \\
\hline ESR (per 1 unit increase) & $-0.02(-0.08$ to 0.04$)$ & 0.393 & 0.124 \\
\hline CRP (per 1 unit increase) & $0.01(-0.07$ to 0.08$)$ & 0.872 & 0.003 \\
\hline
\end{tabular}

$\mathrm{BMI}=$ Body mass index; DAS=Disease activity score; $\mathrm{ESR}=$ Erythrocyte sedimentation rate; $\mathrm{CRP}=\mathrm{C}=$ reactive protein

Table. 4. Meta-regression analysis - Impact of various variables on change in effect size of Right Ventricular Global Longitudinal strain in Rheumatoid Arthritis. 


\begin{tabular}{|c|c|c|c|}
\hline & Estimate (95\% CI) & $P$ & $R^{2}$ \\
\hline Disease Duration (per additional year) & $0.89(-2.09$ to 3.87$)$ & 0.164 & 0.934 \\
\hline Age (per additional year) & $-0.01(-0.40$ to 0.38$)$ & 0.906 & 0.009 \\
\hline Gender (per 1\% increase) & $0.09(-0.01$ to 0.19$)$ & 0.058 & 0.992 \\
\hline CRP (per 1 unit increase) & $0.07(-0.59$ to 0.73$)$ & 0.397 & 0.659 \\
\hline
\end{tabular}

$\mathrm{CRP}=\mathrm{C}$-reactive protein

\section{Figures}

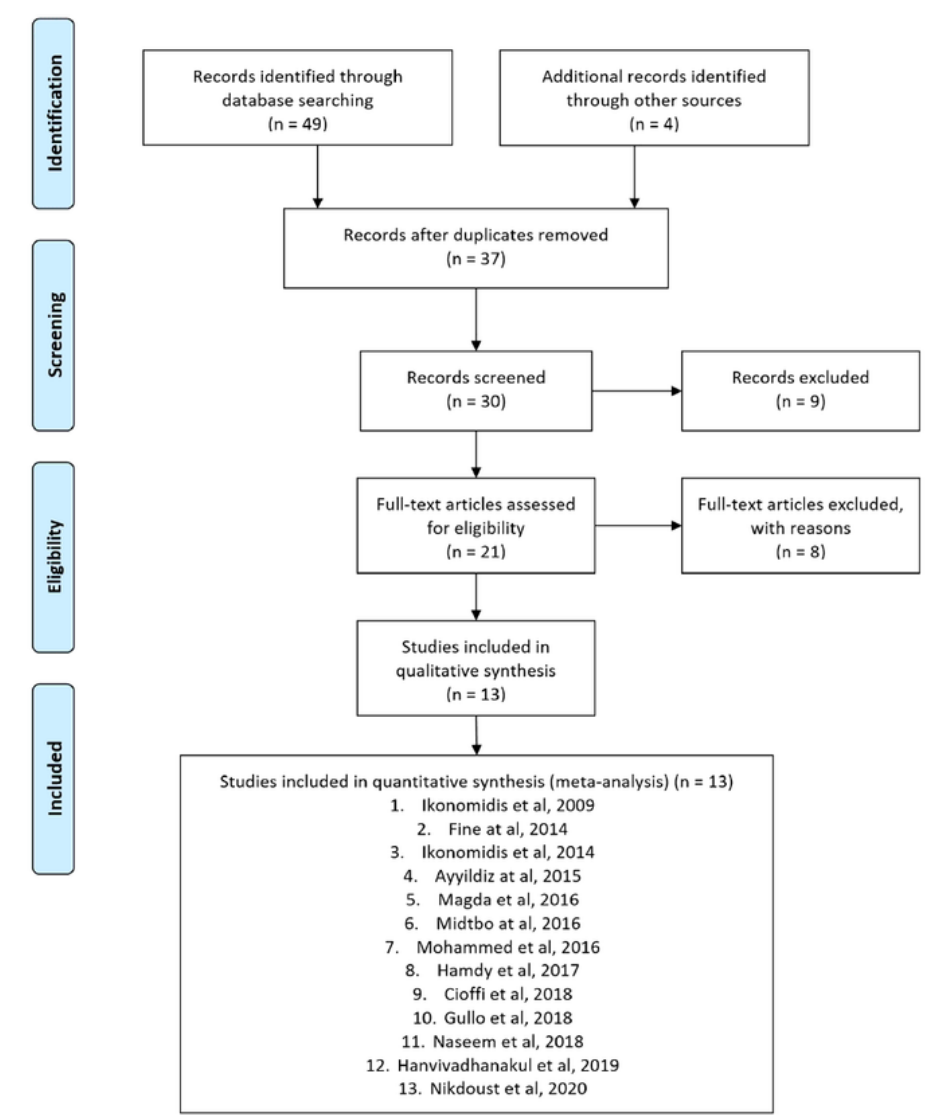

Flow chart showing identification and selection of studies included in the meta- analysis (according to PRISMA guidelines)

\section{Figure 1}

Flow chart showing identification and selection of studies included in the meta-analysis (according to PRISMA guidelines) 


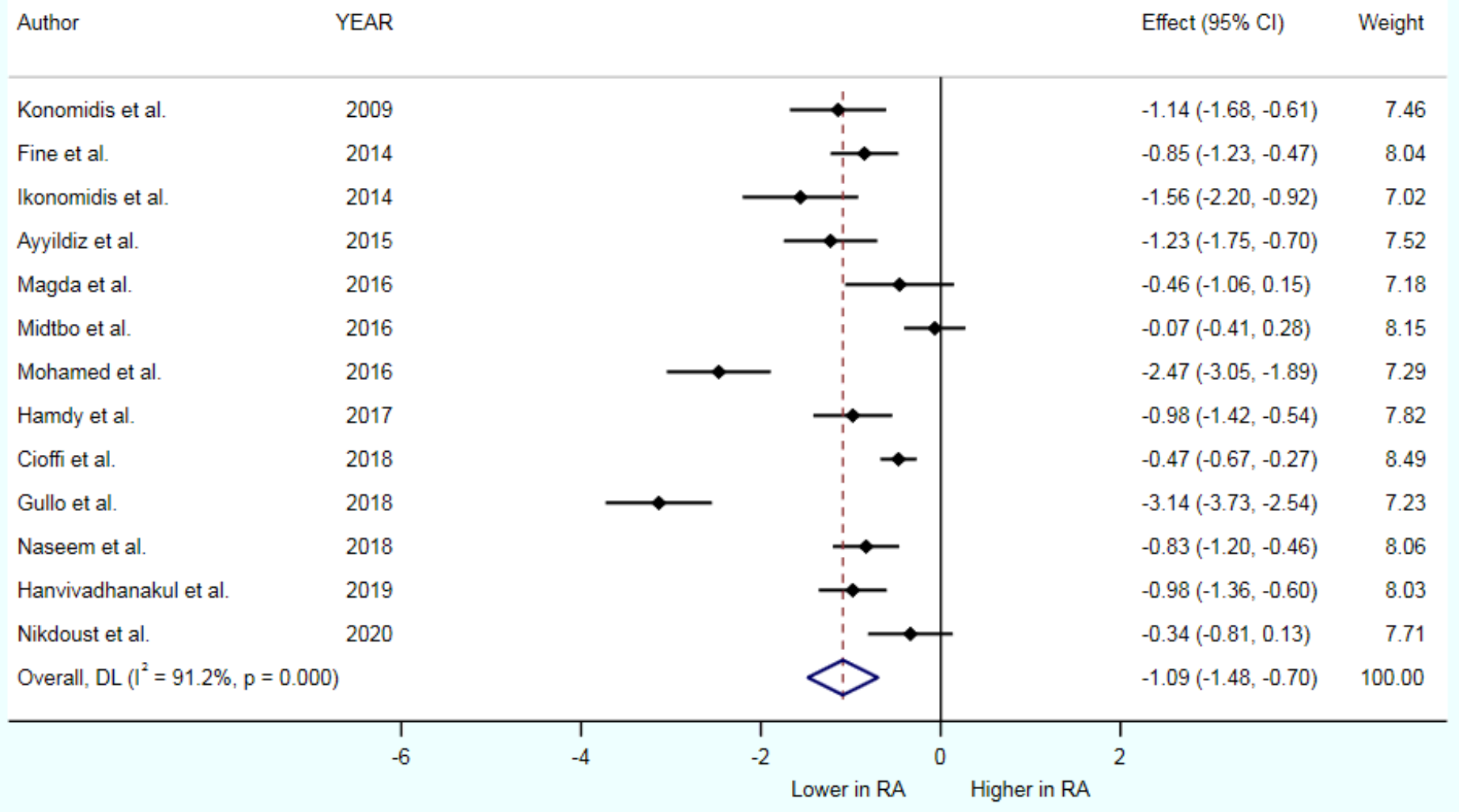

NOTE: Weights are from random-effects model

\section{Figure 2}

Left ventricular Global Longitudinal Strain in patients with Rheumatoid Arthritis (RA) and controls. 


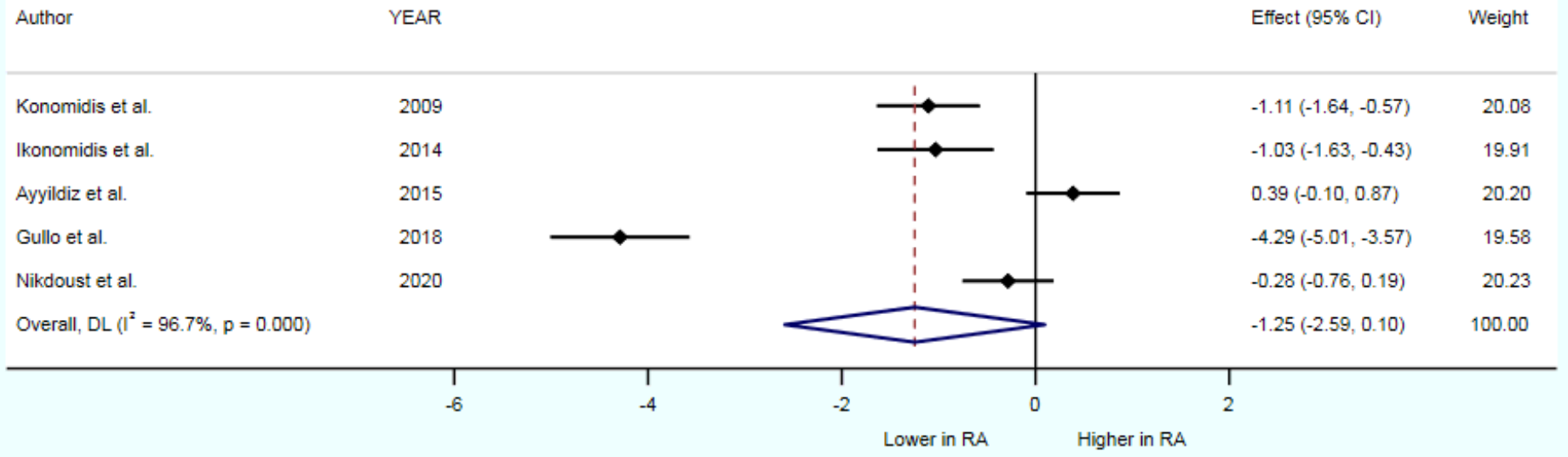

NOTE: Weights are from random-entects model

\section{Figure 3}

Left ventricular Global Circumferential Strain in patients with Rheumatoid Arthritis (RA) and controls. 


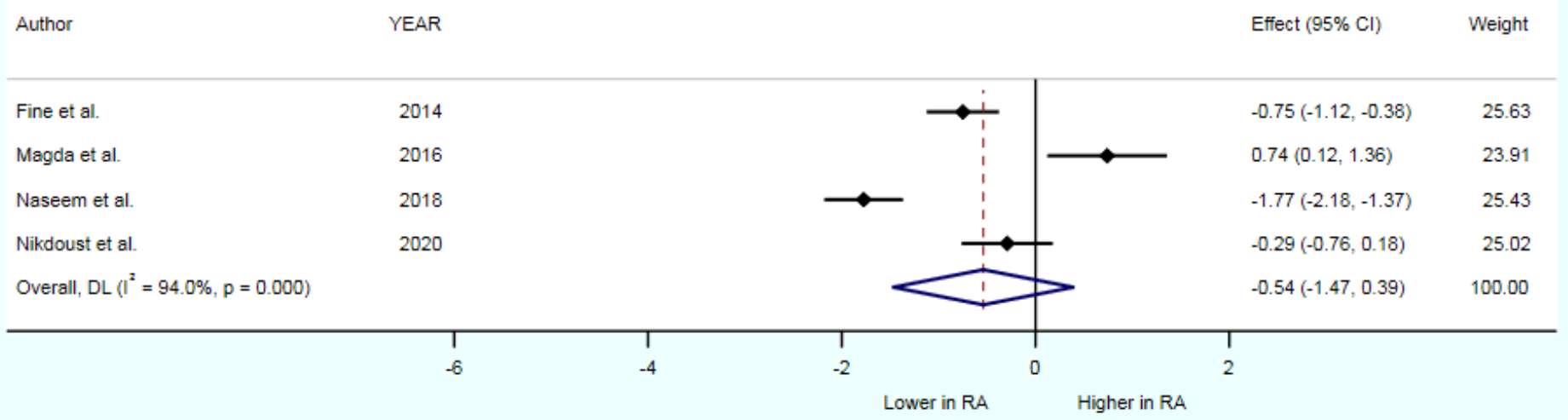

NOTE: Weights are from random-effects model

\section{Figure 4}

Right ventricular Global Longitudinal Strain in patients with Rheumatoid Arthritis (RA) and controls. 